$\left.\begin{array}{l}\text { Sournals } \\ \text { INTERNATIONAL JOURNAL OF } \\ \text { ORGANIZATIONAL LEADERSHIP }\end{array}\right) \begin{gathered}\text { INDUSTRIAL } \\ \text { MANAGEMENT } \\ \text { INSTITUTE }\end{gathered}$

\title{
The effects of organizational culture on the development of strategic thinking at the organizational level
}

\author{
Mohammad Bagher Arayesh $^{1 *}$, Emad Golmohammadi ${ }^{2}$, Maryam Nekooeezadeh $^{3}$, \\ Abbas Mansouri ${ }^{4}$ \\ ${ }^{1}$ Assistant Professor of Ilam Branch, Islamic Azad University, Ilam, Iran \\ ${ }^{2}$ Lecturer at of Scientific - Applied University, Persian 1, Ilam, Iran \\ ${ }^{3}$ Assistant Professor of Management, Shiraz University, Shiraz, Iran \\ ${ }^{4}$ Faculty Member of Political Science, Payam Noor University of Ilam, Ilam, Iran.
}

\begin{abstract}
Keywords:

Organizational Culture, Strategic Thinking, Vision

\section{Received}

12 October 2016

Received in revised form 04 February 2017

Accepted

14 February 2017

Correspondence:

Arayesh.b@gmail.com

Strategic thinking is a strategic capability that helps managers to understand their ability in predicting and controlling future events and distinguishing them. Meanwhile, instead of being placed under the influence of changes, they affect the changes. Organizational culture is a factor that can result in the development of strategic thinking in organizations. The basic purpose of this study is to investigate the effect of organizational culture on the development of strategic thinking at the organizational level of Ilam Gas Refinery. Previous studies mostly used individual models of strategic thinking, while the current study addressed indigenous model of strategic thinking at the organizational level. The research sample included 168 top and middle managers and experts who were selected through simple random sampling. To collect data, Cameron and Quinn's (2006) organizational culture questionnaire and questionnaire of Golmmohammadi, Kafche, and Soltanoanah (2013) were used. Regression and structural equation came into use in data analysis and testing the research hypotheses. The results showed that organizational culture had a significant impact on the strategic thinking at the organizational level. Among the aspects of organizational culture, market's culture was a better explanation for strategic thinking which had a significant positive effect on all aspects of strategic thinking.
\end{abstract}

Culture is an important component of the internal environment. Culture of an organization can be considered as its biggest weakness or strength. Some organizations have been successful in creating the cultures which are completely compatible with organizational needs. 
Organizational culture has a profound impact on organizational decisions and hence it should be considered when reviewing the internal factors. Culture forms the foundation of strategies and affects the elements of the communication process and strategic relationships. If the organization is able to implement strategies to take advantage of its strengths, in that case, management can be easily implemented and would be able to perform any changes very fast. Organizational culture may oppose the new strategies which will lead to confusion. To this end, organizational culture should be in a way that people show interest in formulating strategies (David, 2002).

Culture determines organizational boundaries and creates a feeling of identity in members of the organization. Also, it helps to form a special obligation on members towards achieving organizational goals. Strategic thinking has long been considered as a bargaining chip in economic and social fields. This skill is often ambiguous to many managers at first sight while enhancement of these capabilities will help us in making decisions especially in strategic positions which creates an inability and frustration among managers. Strategic thinking is a particular way of thinking that it can be considered as an architectural skills strategy. Managers believe that successful people think before the operation and then make decisions; this way will reduce the probability of failure. Use of strategic thinking helps us to make the right decision before an operation. Strategic thinking enables managers to assess the risks, benefits, and costs of their decisions.

Uncertainty caused by the two components of change and growing complexity and ambiguity of information are institutionalized in the current environment of stress in today's organizations and ultimately leads to failure for the organization. In these situations, the strategy which operates as a useful tool determines the overall direction for the organization (Rahimnia \& Sadeghian, 2011). Strategic thinking is a good approach for creating strategy in today's business environment. This approach in the intense competitive conditions and unpredictable market behavior is considered as a great advantage (Ghafarian \& Kiani, 2010). Recent studies have identified the lack of strategic thinking among senior management as an affecting factor in the organizational performance. The existence of strategic thinking leads to effecting decision making in the organizations (Goldman, 2012). The ability to think strategically is vital for leaders and managers at different organizational levels (Goldman, 2010). This strategic capability can help managers to understand, detect, predict, and control future events (Golmohammadi et al., 2013).

On the other hand, researchers believe that a community competency to execute its strategy depends on the hardware and software infrastructure because culture and its norms are considered as the foundation of any community software (Thompson \& Strickland, 2003). Organizational culture is effective in organizational decisions and for this reason it should be considered when examining internal factors in the implementation of strategic management (David, 2002). Organizational culture is the foundation of organizational change and strategy implementation (Golmohammadi et al., 2013). Managers who focus on strategic thinking have the appropriate capacity to deal with future problems because they have special attention to a series of items: They first review the organization's situation as it is and it should be and then for gaining competitive advantage in the future market, they revise the way of the use of resources. With strategic thinking they can achieve the desired model of strategic planning in a 
logical and systematic manner. In strategic thinking, intuition and creativity helps administrators to achieve a combination of patterns and different strategies.

Considering the importance of oil and gas industry in the world, Iran's geopolitical situation in the region and existing huge reserves of oil and gas seems to have necessary need to managers and employees with strategic thinking skills in the organizations affiliated to oil and gas industry at different organizational and cultural levels. So far, few studies have investigated the effect of organizational culture on strategic thinking in organizations in the country, especially related to oil and gas industry. Thus, the need for further studies is essential for scientific development in the field. More recent studies have used individual models of strategic thinking but the current study took advantage of the organizational model of strategic thinking. So, this research seeks to identify the impact of organizational culture on the strategic thinking in the gas refinery of Ilam province.

\section{Organizational Culture}

Organizational culture is a set of shared notions or the properties form superior value system in the organization and leads to organizational distinction from other organizations (Rajaee Pour \& Lafti, 2010). Organizational culture is a set of values, beliefs, concepts, deductions, and thinking methods that organizational members have the same features in them (Dargahi, Eskandari, \& Shaham, 2010). The topic of organizational culture requires awareness and recognition across multiple disciplines. Considering different fields, scholars and practitioners concern about learning the different aspects of culture to understand the intangible qualities affecting the effectiveness of workplace environments. While the topic did not create fascination until the early 1980s, searching organizational culture nowadays produces over 3000 studies in the Harvard Business Review alone. Lasting interest in this subject expresses the construct's significance in administrative studies and following this, it mentions the power of culture to influence organizational activities, processes, and outcomes. Organizations enhance particular cultures that eventually affect overall agency success. Culture is an abstract concept applied across multiple academic and social fields with changing contextual meanings. Organizational culture is internal foundation and non-specific structure of organization which manifested on objectives, technology, structure, policies, practices and products of the organization (Amirikermanshahi, 2002). In general, organizational culture is a perception that people have about organization. Following this, it is a set of key values, beliefs, instruction, and the differences that is common between the members of the organization (Moshabaki \& Khazaei, 2008).

In general, organizational culture refers to organizational values which have been notified through norms and human creations (Hogan \& Coote, 2014). Several models of organizational culture have been proposed by researchers such as Hofstadter, Shine, Denison, and Cameron and Quinn. In this study, we used the model of Cameron and Quinn (2006) due to features such as identification of special feature applicable in different organizations and the widespread use of it in the domestic and foreign researches. Competing Values Framework is an approach to explain the different models of organizational effectiveness (Rezvani \& Saham, 2012). In this framework researchers see values as a medium-sized culture. Use of the competing values model as a framework for studying organizational 
culture is indicative of a movement toward taking away a qualitative approach. This model is based on the premise that organizations can be distinguished from each other according to a set of dimensions or cultural traits and common enterprises. It is essential to note that this model comes from models of organizational effectiveness and focuses on the performance of organizations. The first dimension of competing value framework is related to structural dimension of organization. This dimension illustrates clear differences between organic and mechanical forms of organization. The second dimension is related to center of organizational focus. This dimension refers to the distinction between internal measures (internal environment, integrity and unity of the organization) and external measures (external environment, separation, and competition) of organizational effectiveness. The third dimension emphasized the important organizational processes (planning and goal setting) and final results (efficiency or effectiveness) (Ranaei \& Korani, 2007).

They identify, for example, the criteria of effectiveness that must be pursued by organizations, the leadership and managerial competencies that are most effective, and the underlying culture of organizations. Cameron \& Quinn (2006) have introduced four types of organizational culture including Clan (Collaborate, cooperative) with a focus on the organization's internal cohesion and strengthening employee morale; adhocracy (Create) with a focus on organizational flexibility, entrepreneurship, and innovation; market with a focus on competition, efficiency, and productivity; and hierarchy (Control) with a focus on stability and maintaining the current status.

Figure 1 shows the organizational culture model.

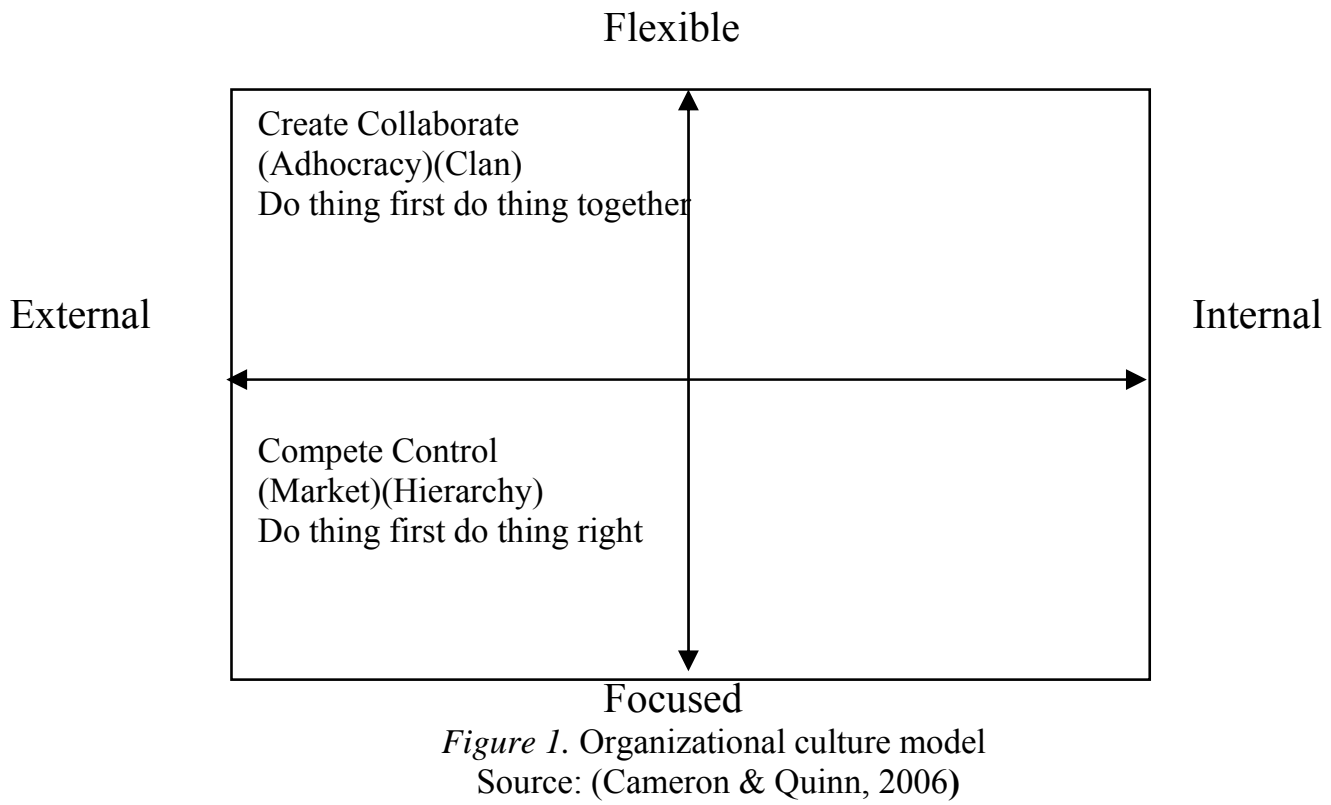

\section{Strategic Thinking}

Strategy is a concept with military roots. Nowadays, areas of strategic thinking are highly regarded and many authors prefer to use them (Farhangi \& Dehghan, 2011). The roots of Strategic Thinking (systematic analysis of the current status and future direction of its formulation) has been considered since the beginning of the twentieth century. Some great 
original ideas include long-term planning; strategic analysis and quality, scenario planning, resource allocation models, organizational culture, leadership, measurement and strategic alignment have been the cornerstone of the development of strategic thinking (Allino, 2006). It covers a broad range of management approaches including development and implementation of an organizational strategic plan. In management literature the difference between the two terms of strategic planning and strategic thinking which led to the creation of confusion in strategic management is not explained (Heracleous, 1998). Mintzberg (1994) believes that planning does not have the ability to develop strategic planning since it involves analytical, formal, executive, and official processes. He also acknowledges that strategic planning was not even in their mature period with financial interests and performance for organizations. Altier (1991) indicates that strategic planning should go away and only strategic thinking can be replaced in its position. Strategic management acts as well when considered as a way to learn not as a way for implementing the version (Goldsmith, 1996).

Bonn (2005) argues that strategic thinking to solve strategic issues has combined with creative thinking and multiple logical approaches. At the same time creativity must be implemented in the real world and utilization of the power of synthesis should be used for analysis of power. Sequential use of strategic thinking and planning is the best way for achieving innovative and creative strategies in practice. Howard (1989) discusses strategic thinking as futurism. He believes that only futurists can have strategic thinking.

Strategic thinking is a process of finding alternative solutions to compete in creating value for customers (Abraham, 2005). To this end, it can be stated that strategic thinking is the result of imagination and fantasy of managers and requires human intuition and creativity while strategic planning is a set of techniques and analytical approach. Strategic management techniques can act as a catalyst for strategic thinking but we must recognize that these techniques should be avoided to limit the creative mind (Goldsmith, 1996).

Takur and Calingor (1992) stated that strategic thinking consists of being active and it involves control and communications center of power. Liedtka (1998) suggests that strategic thinking is a systemic point of view, thinking over time, convergence hypothesis, intentionality, and optimism. He referred to the combination of these elements to have a good outcome for the organization.

Bonne (2001) believes that the presences of three characteristics are required for the fulfillment of strategic thinking. These three characteristics involve a comprehensive understanding of the organization and its environment with reminders and complexity of communications infrastructure and relationships; creativity, new ideas, and reuse application of old ideas; and a vision for the future of the organization.

Several studies have been conducted in the past two decades by researchers such as Bonn (2001), Casey and Goldman (2010), and Liedtka (1998) to conceptualize strategic thinking. In addition to these studies, Goldman (2007) during the past few years by offering learning model attempted to reveal the importance of strategic thinking for managers and organizations. Strategic thinking gives the manager the ability to evaluate the risk, profit, and the costs induced by their decisions. According to Leidtka (1998) having a direction that is not necessarily consistent with available resources and current opportunities, thinking during the 
time of looking to the future with regard to past and present and their relationship; and convergence hypothesis all should be taken into account.

The process begins with innovation. We try to create the ideal future and consider the plans which are essential to achieve. Different samples have been suggested by the thinkers of strategic management so as to model the concept of strategic thinking. Most of the people believe the same as "Looking forward". Strategic thinking focuses on the creation of a better future through future making and also it focuses on increasing value goals in the society through gaining profitable outcomes. Kaufman, Oakley-Brown, Watkins, \& Leigh (2003) outlines six essential factors as success factors drawing strategic thinking.

In the current study we have used the model of Rahmanseresht and Kafche (2008). This model considers strategic thinking factors in the form of content and process factors. Content factors include creativity, vision, and systems thinking. The process factor also includes strategic communications and strategic analysis.

System is a totality that has got at least two properties: First, each one of its parts affects the mechanism or properties of the whole system and second fact is that none of those parts can affect independently on the whole system (Sengupta \& Ackoff, 1965). In strategic thinking, system thinking is to change your viewpoint regarding the organization (Kaufman et al., 2003; Marquardt, 2004). Thinking systematically is a way to see holistically. The main element of system thinking is to change the viewpoint (Liedtka, 1998; Marquardt, 2004). System thinking sees a problem or an opportunity as a part of the whole situation or system (Bonn, 2005; Lieadtka, 1998; Senge, 1990).

The cooperation among business parts which consists of the mutual understanding of internal and external factors should be understood. Strategy and operational strategy of the company are also of high importance (Bonn, 2005; Liedtka, 1998).

Different techniques have been developed to improve creative thinking. When creative minds are cultivated well, it would lead to positive result (Anthony, Dearden, \& Begford, 1989; Rose \& Lin, 1984; Torrance, 1972). In everyone's being, creativity is a combination of three components, namely specialty, creative thinking skills, and motivation; however, managers and strategic thinkers have positive or negative effect through actions or the condition of working environment (Amabile, 1998). Strategic thinker should seek new views to create competitive advantage. One of the creativity conditions is to question common concept. Another way is to connect together the subjects that seem to be irrelevant. It is necessary to combine creativity and the process of strategic thinking which allows the staff and organizations benefit more effectively and make use of the power of their minds in the best way (Bonn, 2005; Mintzberg, 1994).

The view of organization defines its way and direction which helps the organization heighten its success. The learning organization is required to be familiar with the concept of "View". In learning organizations, view is a guide to organization actions; it also motivates the staff and guarantees that organizational processes are in accordance with its view. Therefore, view is considered to be a common goal that makes the staff united and unanimous (Watkins \& Marsick, 1999). In other definitions, "View" has been referred to a plan to achieve future goals of the organization (Howell, 1988). 
It is the future which is more successful and more favorable than its current situation in considerable ways (Boal \& Bryson, 1988; Conger, 1989; Howell, 1988; Kouzes \& Posner, 1987; Yukl, 2006). Some believe that view is created while the others think it exists but should be discovered. In any case, organizational view consists of the process of creation (Collins \& Porras, 1989). A good view should be a combination of different view to depict and visualize the future in a favorable way (Bonn, 2005; Kaufman et al., 2003; Mintzberg, 1994). The combination of these views makes us be dominant in the case of cognition behavior, management, and feeling (Mintzberg, 1998). These factors depend on individual psychological, organizational, and strategic aspects of the members. They state that how organizations can utilize learning to match.

One of the important aspects of this learning is to learn from the customer. The study of market to know customer's behavior and paying attention to its complaints regarding the deep understanding of value creation are considered as common processes of learning from customer. The result of these studies makes known strategies' focus to offer novel successful strategies. Experience is also an important tool for learning from the business environment. To do so, each organization should do necessary actions to plan and fulfill minor low-risk actions.

\section{Strategic Thinking and Organizational Culture}

Culture eats strategy for lunch. This is a statement of management to verify how the strategy will lead to failure regardless of organizational values, beliefs, and assumptions. Therefore, it is obvious that their leaders make great efforts to coordinate culture and organizational strategy (Casey \& Goldman, 2010). Bonn (2005) defines organizational culture as one of the factors affecting the development of strategic thinking. He stated that one aspect of organizational culture is that participation is against hierarchy and authoritarianism. Participation in the decision-making process requires senior managers to be willing to share decision-making with lower-level managers and lower-level managers to be willing in sharing responsibility. In Goldman and Casey's model of strategic thinking (2010), organizational culture is one of the factors that affect the cycle of strategic thinking. They report that creating and changing the organizational culture are among the important functions of leadership. Beliefs about organizational competencies, vision, goals, market, competition, differentiation, and product performance can cause leaders to limit or expand their strategy (Casey \& Goldman, 2010).

Expansion and governance of an organization's culture at different levels of organization leads to the creation of consensus prospective among members to exchange ideas, methods, and goals of the organization. Employees of such organizations put their priorities in line with creativity and innovation according to the organization's goals.

Figure 2 represents the model of learning strategic thinking. 


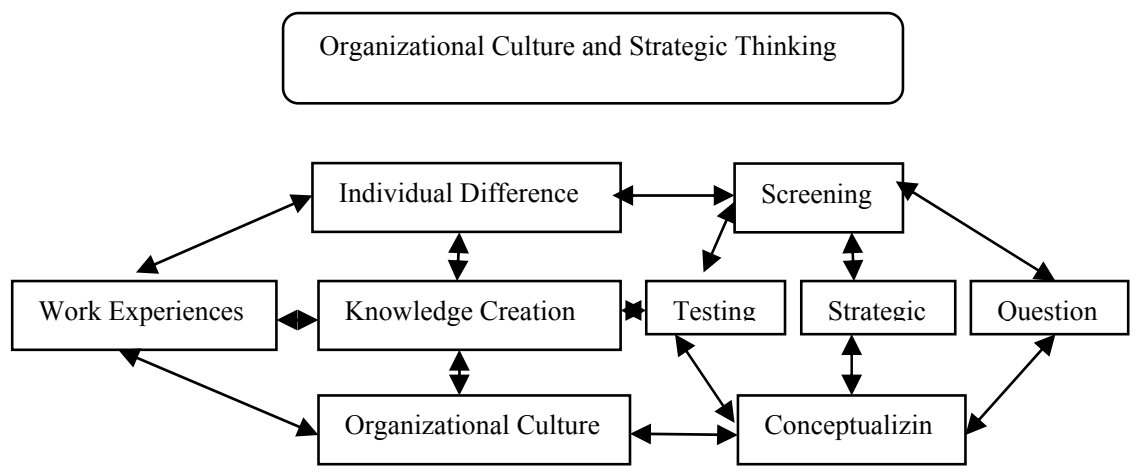

Figure 2. Model of learning strategic thinking

Source: (Goldman \& Casey, 2010)

In this model, organizational culture variables such as work experiences, individual differences, and cultural influences, and strategic thinking such as screening, testing, questioning and conceptualizing for leadership and organizational team development through experimental learning have been studied in relation to each other. In the Moshabaki \& Khazaei's (2008) research it is shown that supporting culture reduces relational conflict and strengthens the conflict related to the duty.

Organizational culture supports ethical and effective behavior. Hosseini and Haji Hosseini (2008) in their study confirmed the impact of culture on strategic thinking.

\section{Conceptual Model of Research}

In this study, the following conceptual model is accepted to study the impact of organizational culture (adhocracy culture, clan culture, market culture, and hierarchical culture) on the strategic thinking at organizational levels (Figure 3).

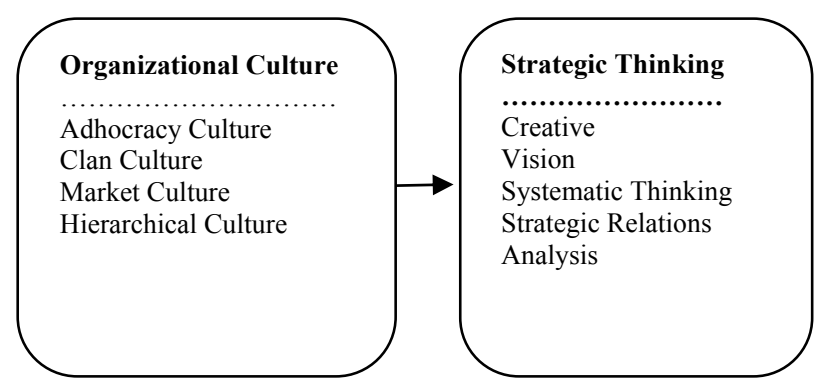

Figure 3. Conceptualizing model of research

\section{Research Hypotheses}

Organizational culture refers to organizational values which have been notified through norms and human creations (Hogan \& Coote, 2014). Several models of organizational culture have been proposed by researchers such as Hofstadter, Shine, Denison, and Cameron and Quinn. We used the model of Cameron and Queen (2006) due to features such as identification of special 
feature applicable in different organizations and the widespread use of it in the domestic and foreign researches. In this study, the model of Cameron \& Quinn (2006) has been accepted as an experimental model for assessing organizational culture variables. They have introduced 4 types of organizational culture including adhocracy culture, clan culture, market culture, and hierarchical culture. In this study we will investigate the causal relationship of each of these components with the components of strategic thinking as dependent variable. Strategic thinking is a process of finding alternative solutions to compete in creating value for customers (Abraham, 2005). To this end, it can be stated that strategic thinking is the result of imagination and fantasy of managers and requires human intuition and creativity while strategic planning is a set of techniques and analytical approach. Strategic management techniques can act as a catalyst for strategic thinking but we must recognize that these techniques should be avoided to limit the creative mind (Goldsmith, 1996). Several studies have been conducted in the past two decades by researchers such as Bonn (2001), Casey and Goldman (2010), and Liedtka (1998) to conceptualize strategic thinking. In addition to these studies, Goldman (2007) during the past few years by offering learning model attempted to reveal the importance of strategic thinking for managers and organizations. In the current study we took advantage of experimental model such as the model of Rahmanseresht and Kafche (2008) and the model of Casey and Goldman (2010). These models consider strategic thinking factors in the form of content and process factors. Content factors include creativity, vision, and systems thinking. The process factor also containes strategic communications and strategic analysis. So to help these two models, 5 variables of strategic thinking, namely creative, vision, systematic thinking, strategic relations, and analysis are determined. Thus, in this study, the research hypotheses have been developed based on experimental models of experts. Finally, we examined the causal relationship between the variables of organizational culture and strategic thinking variables.

\section{Main Hypothesis}

The following main hypothesis guided the study:

- Organizational culture has a positive impact on strategic thinking.

\section{Sub-Hypotheses}

The hypothesis of the research study can have several sub-hypotheses as follows:

- Adhocracy culture has positive impact on strategic thinking

- Clay culture has positive impact on strategic thinking

- Market culture has positive impact on strategic thinking

- Hierarchical culture has positive impact on strategic thinking

\section{Method}

\section{Participants}

The statistical population consisted of 300 people of top managers, middle managers, and experts of Ilam Gas Refinery that 168 of them were selected through simple random sampling method. the sample size has been determined by Morgan table. Based on the goal, the current study was an applied research and in terms of the nature and the method of collecting data, it was a quantity and Survey research. Dependent variable of this study was strategic thinking at 
5 sections (creative, vision, systematic thinking, strategic relations and analysis) and independent variable was organizational culture at 4 sections (adhocracy culture, clan culture, market culture and hierarchical culture).

\section{Data Collection Instrument}

To collect data, Cameron and Quinn's (2006) organizational culture questionnaire with 24 questions in 5 options Likert response (very little, little, average, high, and very high) and questionnaire of Golmmohammadi et al. (2013) in order to measuring variables of strategic thinking with 14 questions in 5 options Likert response (very little, little, average, high, and very high) were used. Questionnaires were popular tools for conducting researches and are considered as direct method of collecting data. The face and content validity of questionnaire were confirmed by a group of university professors and management experts. The Reliability of the research tool was also determined through calculation of ordinal's Theta with helping $\mathrm{R}$ Statistical Software for organizational culture questionnaire $(\Theta=0.88)$. As was observed, all variables have coefficient higher than 0.07 ; this value indicates high reliability of research tool. Regression and structural equation came into use in data analysis and testing the research hypotheses.

Confirmatory factor analysis was conducted in order to verify and finalize the conceptual model. But, before we do that, we must first make sure that existing data can be used for factor analysis. For this purpose, the index sampling adequacy was calculated. Now, we must examine the model consistency with the data collected. The answer to this question is possible by examining model fitting. To determine the model fitting, we used structural equation analysis by taking advantage of statistical software LISREL.

Factor analysis for the variables is listed in Table 1. 
Table 1

Confirmatory Factor Analysis for the Research Variables

\begin{tabular}{|c|c|c|c|}
\hline Variable & Dimension & Representative & Loading Factor \\
\hline \multirow{10}{*}{ Organizational Culture } & \multirow{5}{*}{ Adhocracy } & Q1 & 0.52 \\
\hline & & Q2 & 0.62 \\
\hline & & Q3 & 0.68 \\
\hline & & Q4 & 0.53 \\
\hline & & Q5 & 0.72 \\
\hline & \multirow{5}{*}{ Clan } & Q6 & 0.74 \\
\hline & & Q7 & 0.65 \\
\hline & & Q8 & 0.71 \\
\hline & & Q9 & 0.55 \\
\hline & & Q10 & 0.62 \\
\hline $\mathrm{X}^{2} / \mathrm{df}=1.66$ & \multirow{8}{*}{ Market } & Q11 & 0.68 \\
\hline $\mathrm{GFI}=.91$ & & Q12 & 0.54 \\
\hline $\mathrm{AGFI}=.91$ & & Q13 & 0.68 \\
\hline RMSEA $=.93$ & & Q14 & 0.73 \\
\hline $\mathrm{NFI}=.93$ & & Q15 & 0.69 \\
\hline \multirow{12}{*}{$\begin{array}{c}\mathrm{CFI}=.97 \\
\mathrm{p}=.00\end{array}$} & & Q16 & 0.52 \\
\hline & & Q17 & 0.76 \\
\hline & & Q18 & 0.60 \\
\hline & \multirow{6}{*}{ Hierarchical } & Q19 & 0.67 \\
\hline & & Q20 & 0.66 \\
\hline & & Q21 & 0.82 \\
\hline & & Q22 & 0.81 \\
\hline & & Q23 & 0.76 \\
\hline & & Q24 & 0.61 \\
\hline & \multirow{3}{*}{ Creative } & Q1 & 0.79 \\
\hline & & Q2 & 0.82 \\
\hline & & Q3 & 0.86 \\
\hline \multirow[t]{2}{*}{ Strategic Thinking } & \multirow{3}{*}{ Vision } & Q4 & 0.83 \\
\hline & & Q5 & 0.77 \\
\hline \multirow{9}{*}{$\begin{array}{c}\mathrm{X}^{2} / \mathrm{df}=1.66 \\
\mathrm{GFI}=.91 \\
\text { AGFI }=.91 \\
\text { RMSEA }=.93 \\
\mathrm{NFI}=.93 \\
\mathrm{CFI}=.97 \\
\mathrm{p}=.00\end{array}$} & & Q6 & 0.72 \\
\hline & \multirow{3}{*}{ Systematic Thinking } & Q7 & 0.80 \\
\hline & & Q8 & 0.80 \\
\hline & & Q9 & 0.77 \\
\hline & \multirow{3}{*}{ Strategic Relations } & Q10 & 0.91 \\
\hline & & Q11 & 0.83 \\
\hline & & Q12 & 0.77 \\
\hline & \multirow[t]{2}{*}{ Analysis } & Q13 & 0.78 \\
\hline & & Q14 & 0.85 \\
\hline
\end{tabular}

\section{Results}

\section{Personal Characteristics of the Respondent}

Thirty-eight percent of the statistical sample was between 26-35 years old. Following this, $42.9 \%$ had a master degree and $46 \%$ of the respondents had work experience between 11-15 years.

\section{Investigating Goodness of Fit Index of Structural Model of Basic Hypothesis of Research}

NFI, GFI, and AGFI are fit index of model. The numerical value of these indicators indicates fitness of model. Table 2 contains the most important goodness of fit index of structural model of basic hypothesis of research. These entire indexes indicate the model fit with the observed data. In other words, the model is acceptable and meaningful. 
Table 2

Goodness of Fit Index of Model (Related to Basic Hypothesis)

\begin{tabular}{ccc}
\hline Index Name & \multicolumn{3}{c}{ The Value Obtained } & \\
\cline { 2 - 3 } $\mathrm{X}^{2} / \mathrm{df}$ & The Value Obtained & Acceptable Limits \\
GFI & 2.03 & Less Than 3 \\
RMSEA & 0.91 & Higher Than 0.90 \\
CFI & 0.77 & Less Than 0.10 \\
AGFI & 0.91 & Higher Than 0.90 \\
& 0.91 & Higher Than 0.90 \\
\hline
\end{tabular}

Regarding goodness of fit index of structural model of sub-hypothesis, it can be said that NFI, GFI, and AGFI are fit index of model. The numerical value of these indicators indicates fitness of model. Table 3 presents the most important goodness of fit index of structural model of main hypothesis of research. These entire indexes indicate the model fit with the observed data. In other words, the model is acceptable and meaningful.

Table 3

Goodness of Fit Index of Model (Related to Sub-hypothesis)

\begin{tabular}{ccc}
\hline Index Name & \multicolumn{2}{c}{ The Value Obtained } \\
\cline { 2 - 3 } $\mathrm{X}^{2} / \mathrm{df}$ & The Value Obtained & Acceptable Limits \\
GFI & 1.94 & Less Than 3 \\
RMSEA & 0.94 & Higher Than 0.90 \\
CFI & 0.06 & Less Than 0.10 \\
AGFI & 0.96 & Higher Than 0.90 \\
& 0.93 & Higher Than 0.90 \\
\hline
\end{tabular}

The result of modeling of structural equation research is listed in Table 4.

Table 4

The Result of Modelling of Structural Equation Research

\begin{tabular}{lccc}
\hline Path & Path Coefficient & Significant Coefficient & Result \\
\hline Organizational Culture $\rightarrow$ Strategic Thinking & 0.89 & 11.55 & Accept $\mathrm{H}_{1}$ \\
Clan Culture $\longrightarrow$ Strategic Thinking & 0.86 & 13.76 & Accept $\mathrm{H}_{1}$ \\
Adhocracy Culture $\longrightarrow$ Strategic Thinking & 0.89 & 14.62 & Accept $\mathrm{H}_{1}$ \\
Market Culture $\longrightarrow$ Strategic Thinking & 0.90 & 14.92 & Accept $\mathrm{H}_{1}$ \\
Hierarchical Culture $\longrightarrow$ Strategic Thinking & 0.83 & 13.01 & Accept $\mathrm{H}_{1}$ \\
\hline
\end{tabular}

\section{Testing Research Hypothesis}

In the present study, regression analysis was used to test the research hypotheses and the results are listed in Table 5. 
Table 5

Test Result of Hypotheses

\begin{tabular}{|c|c|c|c|c|c|c|}
\hline Hypothesis & & $\begin{array}{l}\text { Coefficient of } \\
\text { Determination }\end{array}$ & Beta & $\mathrm{T}$ & Sig & Judgment \\
\hline Basic Hypothesis & $\begin{array}{l}\text { Organizational culture has a positive impact on strategic } \\
\text { thinking. }\end{array}$ & 0.66 & 0.81 & 18.03 & 0.000 & Accept $\mathrm{H}_{1}$ \\
\hline Sub Hypotheses 1 & Adhocracy culture has a positive impact on creativity. & 0.61 & 0.40 & 4.25 & 0.000 & Accept $\mathrm{H}_{1}$ \\
\hline Sub Hypotheses 2 & Adhocracy culture has a positive impact on vision & 0.52 & 0.00 & 0.05 & 0.95 & Reject $\mathrm{H}_{1}$ \\
\hline Sub Hypotheses 3 & $\begin{array}{l}\text { Adhocracy culture has a positive impact on systematic } \\
\text { thinking. }\end{array}$ & 0.58 & 0.00 & 0.04 & 0.96 & Reject $\mathrm{H}_{1}$ \\
\hline Sub Hypotheses 4 & $\begin{array}{l}\text { Adhocracy culture has a positive impact on strategic } \\
\text { relations. }\end{array}$ & 0.44 & 0.12 & 1.10 & 0.27 & Reject $\mathrm{H}_{1}$ \\
\hline Sub Hypotheses 5 & $\begin{array}{l}\text { Adhocracy culture has a positive impact on strategy } \\
\text { analysis. }\end{array}$ & 0.39 & 0.13 & 1.15 & 0.25 & Reject $\mathrm{H}_{1}$ \\
\hline Sub Hypotheses 6 & Clay culture has a positive impact on creativity. & 0.61 & 0.02 & 0.28 & 0.77 & Reject $\mathrm{H}_{1}$ \\
\hline Sub Hypotheses 7 & Clay culture has a positive impact on vision. & 0.52 & 0.38 & 3.98 & 0.00 & Accept $\mathrm{H}_{1}$ \\
\hline Sub Hypotheses 8 & $\begin{array}{l}\text { Clay culture has a positive impact on systematic } \\
\text { thinking. }\end{array}$ & 0.58 & 0.23 & 2.60 & 0.01 & Accept $\mathrm{H}_{1}$ \\
\hline Sub Hypotheses 9 & Clay culture has a positive impact on strategic relations. & 0.44 & 0.04 & 0.42 & 0.66 & Reject $\mathrm{H}_{1}$ \\
\hline Sub Hypotheses 10 & Clay culture has a positive impact on strategy analysis. & 0.39 & 0.01 & 0.17 & 0.86 & Reject $\mathrm{H}_{1}$ \\
\hline Sub Hypotheses 11 & Market culture has a positive impact on creativity. & 0.61 & 0.28 & 3.01 & 0.00 & Accept $\mathrm{H}_{1}$ \\
\hline Sub Hypotheses 12 & Market culture has a positive impact on vision. & 0.52 & 0.22 & 2.13 & 0.03 & Accept $\mathrm{H}_{1}$ \\
\hline Sub Hypotheses 13 & $\begin{array}{l}\text { Market culture has a positive impact on systematic } \\
\text { thinking. }\end{array}$ & 0.58 & 0.34 & 3.51 & 0.00 & Accept $\mathrm{H}_{1}$ \\
\hline Sub Hypotheses 14 & $\begin{array}{l}\text { Market culture has a positive impact on strategic } \\
\text { relations. }\end{array}$ & 0.44 & 0.43 & 3.89 & 0.00 & Accept $\mathrm{H}_{1}$ \\
\hline Sub Hypotheses 15 & $\begin{array}{l}\text { Market culture has a positive impact on strategy } \\
\text { analysis. }\end{array}$ & 0.39 & 0.44 & 4.88 & 0.00 & Accept $\mathrm{H}_{1}$ \\
\hline Sub Hypotheses 16 & Hierarchy culture has a positive impact on creativity. & 0.61 & 0.13 & 1.63 & 0.10 & Reject $\mathrm{H}_{1}$ \\
\hline Sub Hypotheses 17 & Hierarchy culture has a positive impact on vision. & 0.52 & 0.17 & 1.97 & 0.05 & Reject $\mathrm{H}_{1}$ \\
\hline Sub Hypotheses 18 & $\begin{array}{l}\text { Hierarchy culture has a positive impact on systematic } \\
\text { thinking. }\end{array}$ & 0.58 & 0.25 & 3.00 & 0.00 & Accept $\mathrm{H}_{1}$ \\
\hline Sub Hypotheses 19 & $\begin{array}{l}\text { Hierarchy culture has a positive impact on strategic } \\
\text { relations. }\end{array}$ & 0.44 & 0.19 & 1.98 & 0.04 & Accept $\mathrm{H}_{1}$ \\
\hline Sub Hypotheses 20 & $\begin{array}{l}\text { Hierarchy culture has a positive impact on strategy } \\
\text { analysis. }\end{array}$ & 0.39 & 0.08 & 0.86 & 0.39 & Reject $\mathrm{H}_{1}$ \\
\hline
\end{tabular}

Organizational culture had positive impact on strategic thinking. From 20 sub-hypotheses, 10 sub hypotheses were accepted and 10 sub hypotheses were rejected. In addition, structural equation modeling was used to estimate the final research model. The final research model is listed in both the standard and the significant estimates.

As it is illustrated, the validity and fitness of the research model were confirmed. In this model, all factors had direct statistically meaningful relationship. Figure 5 depicts the research structural model in the significant mode.

All coefficients of structural mode are significant between organizational culture and strategic thinking. As a result, it can be concluded that there is a significant relationship between these two variables.

\section{Discussion and Conclusion}

The aim of the present study was to investigate the effect of organizational culture on the development of strategic thinking at the organizational level of Ilam Gas Refinery. Theoretical framework of this study demonstrates the importance and impact of organizational culture on strategy and strategic thinking. The results showed that culture with beta coefficient of 0.84 has high impact on strategic thinking which confirms the findings of Casey and Goldman (2010), Moshabaki and Khazaei (2008), and Hosseini and Haji Hosseini (2008). Results of the study showed that among the aspects of strategic thinking, culture adhocracy has effect on creativity. 
Also, Clay culture is effective on the aspects of vision and systematic thinking. Culture market has a significant effect on all aspects of the strategic thinking and has the greatest impact on the strategic analysis. Hierarchical culture has a significant effect on the dimensions of vision, systems thinking, and strategic communication.

The results showed that organizational managers should pay attention to organizational culture to enhance and promote strategic thinking at the organizational levels. Because the market culture has an impact on all aspects of the strategic thinking it is recommended that managers encourage employees to be innovative and creative. Collaboration with different levels of managers and employees, creating clear vision, avoiding the superficiality, and institutionalizing a systematic thinking and attitudes in organizations should be welcomed in brainstorming the views of employees about entering new markets and developing products.

The findings of this study should be viewed within the context of its limitations. The study took advantage of questionnaires in gathering data. To this end, in subsequent studies, researchers could make use of assessment tools such as observation, interviewing or combination of different assessment devices. Since the study was conducted only in Ilam Gas Refinery, further research in other institutions is needed in order to compare the results.

\section{References}

Abraham, S. (2005). Stretching strategic thinking. Strategy \& Leadership, 33(5), 5-12.

Allino, R. J. (2006). Strategic thinking: The ten big ideas. Strategy \& Leadership, 34(4), 4-13.

Altier, W. J. (1991). Strategic thinking for today's corporate battles. Management Review, 8, 20-22.

Amabile, T. M. (1998). How to kill creativity? Harvard Business Review, 76(5), 76-87.

AmiriKermanshahi, M. (2002). Culture and Organization. Journal of Administrative Changes, 4, $28-36$.

Anthony, R., Dearden, J., \&Begford, N. M. (1989). Management Control Systems (6 ${ }^{\text {th }}$ ed.). Homewood, IL: Irwin.

Boal, K. B., \& Bryson, J. M. (1988). Charismatic leadership: A phenomenological and structural approach. In J. G. Hunt, B. R. Baligia, H. P. Dachler, \& C. A. Schriesheim (Eds.), Emerging leadership vistas (pp.11-28). Lexington, MA: Lexington Books.

Bonn, I. (2001). Developing strategic thing as a core competency. Management Decision, 39(1), 63-70.

Bonn, I. (2005). Improving strategic thinking: A multilevel approach. Leadership \& Organization Development Journal, 26(5), $336-354$.

Cameron, K. S., \& Quinn, R. E. (2006). Diagnosing and changing organizational culture: Based on the competing values framework. San Francisco, AC: Jossy-Bass.

Casey, A., \& Goldman, E. (2010). Enhancing the ability to think strategically: A learning model. Management Learning, 41(2), $167-185$.

Collins, J. C., \& Porras, J. I. (1989). Making impossible dreams come true. Stanford Business School Magazine, 57(1), 12-19.

Conger, J. A. (1989). The charismatic leader: Beyond the mystique of exceptional leadership. San Francisco: Jossey-Bass.

Dargahi, H., Eskandari, M., \& Shaham, G. (2010). Comparing current organizational culture and desirable organizational culture from executive managers' point of view in hospitals of Tehran Medical Sciences University. Journal of College of Tehran University of Medical Sciences, 4(1/2), 72-87.

David, F. R. (2002). Strategic management: Concepts and cases. Upper Saddle River: Prentice Hall.

Farhangi, A. A., \& Dehghan, M. (2011). Factors affecting the strategic thinking. Marketing Management, 9, $32-43$.

Ghafarian, V., \& Kiani, G. R. (2010). Five Commands of strategic thinking. Tehran: Fara Cultural Organization.

Gholmohammadi, E., Kafche, P., \& Soltanoanah, H. (2013). Leadership styles and strategic thinking at the organizational level. Strategic Management Studies, 15, 93-114.

Goldman, E. F. (2007). Strategic thinking at the top. MIT Sloan Management Review, 48(4), 75-81. 
Goldman, E. F. (2010). The power of work experiences: Characteristics critical to developing expertise in strategic thinking. Human Resource Development Quarterly, 19(3), 217-239.

Goldman, E. F. (2012). Leadership practices that encourage strategic thinking. Journal of Strategy \& Management, 5(1), 2540.

Goldman, E. F., \& Casey, A. (2010). Building a culture that encourages strategic thinking. Journal of Leadership \& Organizational Studies, 17, 119-128.

Goldsmith, A. (1996). Strategic thinking in international development: Using management tools to see the big picture. World Development, 24(9), 1431-1439.

Heracleous, L. (1998). Strategic Thinking or Strategic Planning? Long Range Planning, 31(3), 481-487.

Hogan, S. J., \& Coote, L. V. (2014). Organizational culture, innovation, and performance: A test of Schein's model. Journal of Business Research, 67(8), 1609-1621.

Hosseini, S. Y., \& Haji Hosseini, E. (2008). An investigation of the influence of organizational culture on strategic thinking. Paper presented at the Fifth International Conference on Strategic Management, Tehran, Iran.

Howard, E. F. (1989). Strategic thinking in insurance. Long Range Planning, 22(5), 76-79.

Howell, J. M. (1988). Two faces of charisma: Socialized and personalized leadership in organizations. In J. A. Conger \& R. N. Kanungo (Eds.), Charismatic leadership: The elusive factor in organizational effectiveness (pp. 213-236). San Francisco, CA: Jossey-Bass.

Kaufman, R., Oakley-Brown, H., Watkins, R., \& Leigh, D. (2003). Strategic planning for success: Aligning people, performance and payoffs. San Francisco: Jossey Bass.

Kouzes, J. M., \& Posner, B. Z. (1987). The leadership challenge. San Francisco, CA: Jossey-Bass.

Liedtka, J. M. (1998). Strategic thinking: Can it be taught? Long Range Planning, 31(1), 120-129.

Marquardt, M. (2004). Harnessing the power of action learning. Training \& Development, 58(6), $26-32$.

Mintzberg, H. (1994). The rise and fall of strategic planning. New York: Free Press.

Mintzberg, H. (1998). Strategic thinking as seeing, In B. Garratt (Eds.), Developing strategic thought: Reinventing the art of direction. London: McGraw-Hill.

Moshabaki, A., \& Khazaei, A. (2008). Designing a model of elements of strategic thinking in the Iranian organizations. Journal of Business Management, 1(1), 105-118

Rahimnia, F., \&Sadeghian, S. H. (2011). The strategic orientation and the success of exporting companies. Human Resource Management Research, 1(1), 115-136.

Rahmanseresht, H., \& Kafche, P. (2008). Organizational model for strategic thinking. Journal of Business Management, 28, $47-77$.

Rajaee Pour, S., \& Lafti, S. (2010). Surveying the relationship between organizational culture and management components based on organizational values and providing a model for predicting management based on values. Journal of New Approach in Educational Management, 4, 28-44.

Ranaei, H., \& Korani, F. (2007). Application of competing values framework in organizational culture researches. Management Culture, 15, 89-116.

Rezvani, H. R., \& Saham, M. (2012). Comparative study of typology of organizational culture. Governmental Management, 3(6), 79-92.

Rose, L. H., \& Lin, H. T. (1984). A meta-analysis of long-term creativity training programmers. Journal of Creative Behavior, $18(1), 11-22$.

Senge, P. M. (1990). The fifth discipline: The art and practice of the learning organization. New York: Currency Doubleday.

Sengupta, S. S., \& Ackoff, R. L. (1965). System theory from an operations research point of view. Journal of General System, $10,43-48$.

Thakur, M., \& Calingo, L. R. (1992). Strategic thinking is hip, but does it make a difference? Business Horizons, 35(5), 47-54.

Thompson, A. A., \& Strickland A. J. (2003). Strategic management: Concepts and cases. Tata McGraw- Hill: New Delhi.

Torrance, E. P. (1972). Can we teach children to think creatively? Journal of Creative Behavior, 6(2), 114-143.

Watkins, K. E., \& Marsick, V. J. (1999). Sculpting the learning community: New forms of working and organizing. National Association of Secondary School Principals: NASSP Bulletin, 83(604), 78-87.

Yukl, G. A. (2006). Leadership in organizations ( $6^{\text {th }}$ ed.). Upper Saddle River, NJ: Pearson-Prentice Hall. 